\title{
Acute and Long-Term Suppression of Feeding Behavior by POMC Neurons in the Brainstem and Hypothalamus, Respectively
}

\author{
Cheng Zhan, ${ }^{1 \star}$ Jingfeng Zhou, ${ }^{1,2 \star}$ Qiru Feng, ${ }^{1}$ Ju-en Zhang, ${ }^{1}$ Shuailiang Lin, ${ }^{1}$ Junhong Bao, ${ }^{1}$ Ping Wu,${ }^{1}$ and \\ Minmin Luo ${ }^{1,3}$ \\ ${ }^{1}$ National Institute of Biological Sciences, Beijing 102206, China, ${ }^{2}$ PTN Graduate Program, School of Life Sciences, Peking University, Beijing 100081, China, \\ and ${ }^{3}$ School of Life Sciences, Tsinghua University, Beijing 100084, China
}

POMC-derived melanocortins inhibit food intake. In the adult rodent brain, POMC-expressing neurons are located in the arcuate nucleus (ARC) and the nucleus tractus solitarius (NTS), but it remains unclear how POMC neurons in these two brain nuclei regulate feeding behavior and metabolism differentially. Using pharmacogenetic methods to activate or deplete neuron groups in separate brain areas, in the present study, we show that POMC neurons in the ARC and NTS suppress feeding behavior at different time scales. Neurons were activated using the DREADD (designer receptors exclusively activated by designer drugs) method. The evolved human M3-muscarinic receptor was expressed in a selective population of POMC neurons by stereotaxic infusion of Cre-recombinase-dependent, adenoassociated virus vectors into the ARC or NTS of POMC-Cre mice. After injection of the human M3-muscarinic receptor ligand clozapine$\mathrm{N}$-oxide ( $1 \mathrm{mg} / \mathrm{kg}$, i.p.), acute activation of NTS POMC neurons produced an immediate inhibition of feeding behavior. In contrast, chronic stimulation was required for ARC POMC neurons to suppress food intake. Using adeno-associated virus delivery of the diphtheria toxin receptor gene, we found that diphtheria toxin-induced ablation of POMC neurons in the ARC but not the NTS, increased food intake, reduced energy expenditure, and ultimately resulted in obesity and metabolic and endocrine disorders. Our results reveal different behavioral functions of POMC neurons in the ARC and NTS, suggesting that POMC neurons regulate feeding and energy homeostasis by integrating long-term adiposity signals from the hypothalamus and short-term satiety signals from the brainstem.

\section{Introduction}

POMC neurons play critical roles in maintaining normal feeding behavior and energy homeostasis (Schwartz et al., 2000; Morton et al., 2006). Genetic and pharmacological studies have revealed that the activity of POMC neurons functions to reduce appetite, enhance metabolism, and increase energy expenditure. Ablating POMC neurons in the entire brain or mutating the POMC gene causes obesity in rodents and humans (Yaswen et al., 1999; Coll et al., 2004; Gropp et al., 2005; Xu et al., 2005). Intraventricular administration of POMC-derived melanocortins such as $\alpha$-melanocyte-stimulating hormone

Received June 8, 2012; revised Jan. 1, 2013; accepted Jan. 10, 2013.

Author contributions: C.Z. and M.L. designed research; C.Z., J.Z., Q.F., J.-e.Z., S.L., J.B., and P.W. performed research; C.Z. and J.Z. analyzed data; C.Z. and M.L. wrote the paper.

M.L. is supported by a China Ministry of Science and Technology 973 Grant (2010 CB833902). We thank D. Duan (University of Missouri) for technical advice on virus preparation, J. Zhang (Nanjing University of Science and Technology) for assistance with measuring body composition, Z. Sheng [National Institute of Biological Sciences (NIBS)] for corticosterone assays; Z. Zhao (NIBS) for help with behavior tests; and G. Zhi, E. Zhang, and L. Mu (NIBS) for advice and comments.

${ }^{*}$ C.Z. and J.Z. contributed equally to this work.

The authors declare no competing financial interests.

Correspondence should be addressed to either Cheng Zhan or Minmin Luo, National Institute of Biological Sciences, 7 Science Park Road, Zhongguancun Life Science Park, Beijing 102206, China, E-mail: zhancheng@nibs.ac.cn or luominmin@nibs.ac.cn.

DOI:10.1523/JNEUROSCI.2742-12.2013

Copyright $\odot 2013$ the authors $\quad 0270-6474 / 13 / 333624-09 \$ 15.00 / 0$
( $\alpha$-MSH) or its analogs suppresses food intake within hours (Fan et al., 1997).

In the adult rodent brain, a majority of POMC neurons are located in the arcuate nucleus (ARC) of the hypothalamus (Cone, 2005; Padilla et al., 2012). Moreover, melanocortin receptors are richly expressed in the downstream stations targeted by ARC POMC neurons (Cone, 2005), suggesting that these neurons consist of a fundamental component in the neural circuit underlying feeding inhibition. However, optogenetic stimulation of POMC neurons in the ARC for $2 \mathrm{~h}$ does not inhibit food intake (Aponte et al., 2011), implying that there are additional neuronal populations that mediate the acute inhibitory effect of melanocortin signaling. In addition to the ARC, the nucleus tractus solitarius (NTS) in the medulla also contains a substantial number of POMC-expressing neurons (Bronstein et al., 1992; Padilla et al., 2012). The exact functional significance of these two different groups of POMC neurons has not been studied directly.

In this study, we examined the behavioral functions of POMC neurons by separately stimulating or ablating these two neuron populations. We used the DREADD (designer receptors exclusively activated by designer drugs) method for neuron activation (Armbruster et al., 2007; Alexander et al., 2009). The gene encoding the evolved human M3-muscarinic receptor (hM3Dq) was targeted selectively into POMC neurons in the ARC or NTS with a Cre-inducible adeno-associated virus (AAV) vector that carries a "double-floxed" inverted open reading frame (AAV DIO) (Ata- 
soy et al., 2008; Dong et al., 2010; Krashes et al., 2011). Neurons were activated remotely by injection of the hM3Dq ligand clozapine- $\mathrm{N}$-oxide (CNO). After discovering that feeding suppression required stimulation of these two neuron groups at different time scales, we went on to investigate the necessity of these neurons in maintaining energy homeostasis. A similar strategy of AAV vector design was used to express diphtheria toxin receptor (DTR) in POMC neurons in the ARC or NTS for later neuron lesion with the injection of DT (Buch et al., 2005; Gropp et al., 2005; Luquet et al., 2005). Our results indicate that ablating POMC neurons in the ARC but not the NTS produces obesity and metabolic disorders. These findings highlight the functional heterogeneity among brain POMC neurons, suggesting that the ARC and NTS POMC neurons contribute to maintaining longterm energy homeostasis and controlling short-term food intake, respectively.

\section{Materials and Methods}

Mice. Animal care and use conformed to institutional guidelines of the National Institute of Biological Sciences (Beijing, China) and to governmental regulations. All experiments were performed on adult $(8-16$ weeks of age) POMC-Cre mice of either sex expressing Cre recombinase under POMC promoter control [strain name $\mathrm{Tg}$ (Pomcl-cre)16Lowl/J, The Jackson Laboratory] (Balthasar et al., 2004). Cre recombinase in these mice has been shown to mediate recombination of floxed alleles efficiently in neurons within the ARC and NTS (Balthasar et al., 2004; Huo et al., 2006). In the ARC of these mice, Cre recombinase drives the expression of marker proteins that colocalize with POMC immunoreactivity. In the NTS, the distribution pattern of Cre-expressing neurons resembles that of neurons expressing POMC mRNA (Balthasar et al., 2004; Huo et al., 2006), but the precise identity of Cre-expressing neurons has not been tested with POMC immunohistochemistry. Mice were housed under controlled temperature $\left(22-25^{\circ} \mathrm{C}\right)$ and $12 \mathrm{~h}$ light/dark cycles (light time, 9:30 P.M. to 9:30 A.M.) with standard chow diet (4\% fat SPF Rodent Feed, Bejing Keao Xieli Feed Co.) and ad libitum drinking water.

$A A V$ vectors for $h M 3 D q$ or DTR expression. We used Cre-inducible AAV vectors with an AAV DIO carrying the specific genes in the antisense orientation (Atasoy et al., 2008). The coding sequence of hM3Dq2A-mCherry, DTR, or mCherry was inserted into an AAV DIO vector with a CMV early enhancer/chicken $\beta$-actin (CAG) promoter (see Figs. $1 A, B, 4 A$ ). All coding sequences were in a $3^{\prime}$ to $5^{\prime}$ orientation relative to the promoter. The vectors were then sequenced and packaged in AAV serotype 2/9 vectors consisting of AAV2 ITR genomes pseudotyped with AAV9 serotype capsid proteins. AAV vectors were replicated in HEK293 cells with the triple plasmid transfection system purified by cesium chloride-density gradient centrifugation and desalination via dialysis against a physiological buffer (Duan et al., 2001), resulting in AAV vector titers of $>10^{9}$ particles $/ \mu$ l.

Stereotaxic virus injection. Mice were injected with atropine $(0.05 \mathrm{mg} /$ $\mathrm{kg}$, i.p.) and anesthetized with pentobarbital ( $80 \mathrm{mg} / \mathrm{kg}$, i.p.), placed in a temperature-controlled stereotaxic holder (BrainKing Biotech), and a small hole was opened in the skull. Pulled glass pipettes $(\sim 20 \mu \mathrm{m}$ tip diameter) were filled with AAV and inserted into specific brain areas. For the ARC, AAV vectors (500 or $1000 \mathrm{nl}$ ) were infused with pressure (coordinate AP/DV/ML $=-1.7 /-5.5 / \pm 0.2 \mathrm{~mm}$; infusion speed $=23 \mathrm{nl} /$ min; Nanoliter 2000 Injector, WPI). For the NTS, $500 \mathrm{nl}$ of vector was injected into the medulla (coordinate $=-8.4 /-3.3 / 0 \mathrm{~mm}$ ). To activate neurons, AAV DIO hM3Dq-2A-mCherry vectors were injected into the ARC or NTS of POMC-Cre mice, which for simplicity are referred to as ARC ${ }^{\text {hMBDq }}$ mice and NTS ${ }^{\text {hM3Dq }}$ mice, respectively. To ablate neurons, AAV DIO DTR vectors were injected into the ARC or NTS of POMC-Cre mice (referred to as ARC ${ }^{\text {DTR }}$ mice and NTS ${ }^{\text {DTR }}$ mice, respectively) and DT was injected $14 \mathrm{~d}$ later. To confirm lesion effects in the NTS, AAV DIO mCherry vectors were injected into the NTS of NTS ${ }^{\text {DTR }}$ mice after behavioral studies. For control, AAV DIO mCherry virus was injected into the ARC or NTS of POMC-Cre mice (referred to as ARC ${ }^{\text {mCherry }}$ mice and NTS ${ }^{\text {mCherry }}$ mice, respectively). Mice were allowed to recover in individual cages for at least 2 weeks before the behavioral assays.

Measurement of food intake, meal pattern, body weight, and body mass composition. To measure food intake, each test cage was equipped with an individual food station that was placed on a digital scale (Zhenquan Technology). Food weight was recorded online through RS232 ports. $\mathrm{ARC}^{\mathrm{hM} 3 \mathrm{Dq}}$ mice or NTS ${ }^{\mathrm{hM} 3 \mathrm{Dq}}$ mice were first injected with saline during the first $2 \mathrm{~d}(1 \mu \mathrm{l} / \mathrm{g}$ body weight, i.p.) at dark onset. They were then supplied with a single dose of CNO (1 mg/kg body weight in saline i.p.; 1 $\mu \mathrm{l} / \mathrm{g}$ ) at dark onset during the next $2 \mathrm{~d}$. On days 5 and 6 , mice were given two injections of $\mathrm{CNO}$, first at dark onset and then $5 \mathrm{~h}$ later. After the application of either saline or $\mathrm{CNO}$, cumulative food intake at different time points $(2,5,8,10,12$, and $24 \mathrm{~h})$ were measured. The same procedures were performed in ARC ${ }^{\text {mCherry }}$ mice and NTS ${ }^{\text {mCherry }}$ mice to control the effect of CNO. The values of meal number and meal size were quantified using methods described previously (Zorrilla et al., 2005). Briefly, food intake after dark onset was recorded every $5 \mathrm{~min}$ for $5 \mathrm{~h}$. The minimal intermeal interval was $15 \mathrm{~min}$ and the criterion of minimal meal size was $50 \mathrm{mg}$. To examine the effects of chronic $\mathrm{CNO}$ application on $\mathrm{ARC}^{\mathrm{hM} 3 \mathrm{Dq}}$ mice and NTS ${ }^{\mathrm{hM} 3 \mathrm{Dq}}$ mice, animals received saline injections every $5 \mathrm{~h}$ during the first $2 \mathrm{~d}$, then CNO injections every $5 \mathrm{~h}$ for $3 \mathrm{~d}$.

To kill POMC neurons, ARC ${ }^{\text {DTR }}$ mice and NTS ${ }^{\text {DTR }}$ mice were given a single injection of DT ( $50 \mu \mathrm{g} / \mathrm{kg}$, i.p.). ARC ${ }^{\text {mCherry }}$ mice and NTS ${ }^{\text {mCherry }}$ mice were provided with the same dose of DT as a control. The body weights and food intakes of all DT-treated mice were monitored on a daily basis for 4 weeks. One month after DT injection, whole-body mass composition was examined with a benchtop nuclear magnetic resonance analyzer (Minispec Live Mouse Analyzer, Bruker).

Glucose tolerance tests and serum assays. One month after DT application, mice were fasted with free access to water $3 \mathrm{~h}$ before light onset. After $16 \mathrm{~h}$ of fasting, the end of the tail was cut horizontally with a razor blade and a small drop of blood was collected with gentle massaging for the measurement of baseline blood glucose level using a blood glucose meter (One Touch, Johnson \& Johnson Medical). Mice were then given a $20 \%$ glucose solution ( $2 \mathrm{~g} / \mathrm{kg}$ body weight, i.p.) and blood glucose levels were further sampled at the time points of $15,30,60,90$, and $120 \mathrm{~min}$.

Lipid metabolism and corticosterone levels were measured $\sim 40 \mathrm{~d}$ after DT injections. After overnight fasting, mice were anesthetized with isoflurane. Blood was drawn from the retrobulbar intraorbital capillary plexus and serum was then separated by centrifugation. Serum levels of total cholesterol, triglycerides, high-density lipoprotein cholesterol, and low-density lipoprotein cholesterol were analyzed by the Institute of Laboratory Animal Sciences at the Chinese Academy of Medical Sciences. The serum corticosterone levels were measured with a commercial corticosterone ELSA kit (catalog \#ADI-900-097, Enzo Life Sciences).

Measurement of locomotor activity and oxygen consumption. The locomotor activity level of each mouse was quantified by measuring the total travel distance using a method described previously (Bjursell et al., 2008; Gong et al., 2011; Klockener et al., 2011). Twenty days after DT treatment, mice were placed in a test cage $(30 \times 30 \mathrm{~cm})$ with an overhead infrared camera (KVS-5096S, Wanzhongxin Technology). Animal movement was videotaped at $5 \mathrm{fps}$ and the horizontal locomotor activity was analyzed online with a custom-written MATLAB program. The travel distance of an individual mouse was clustered into different time periods in a day and then averaged across the test period of $6 \mathrm{~d}$. Oxygen consumption was measured with an open-circuit calorimeter system (AccuScan Instruments). The measurement was taken every $2 \mathrm{~min}$ for $2 \mathrm{~h}$ during light cycles with room air as a reference and an air flow to the chambers of $0.5 \mathrm{l} / \mathrm{min}$. Data were normalized to body weight.

Histology, immunostaining, and imaging. For c-Fos immunostaining, mice received an i.p. injection of either saline or CNO $(1 \mathrm{mg} / \mathrm{kg})$. Ninety minutes later, mice were anesthetized $(300 \mathrm{mg} / \mathrm{kg}$ pentobarbital, i.p.) and perfused transcardially with cold saline and $4 \%$ paraformaldehyde in the PBS with $0.2 \%$ picric acid. Brains were extracted and postfixed in $4 \%$ paraformaldehyde overnight at $4^{\circ} \mathrm{C}$ and cryoprotected with $30 \%$ sucrose. Coronal sections $(30-40 \mu \mathrm{m})$ were cut with a cryostat (CR 1900, Leica) and mounted on glass slides. Brain sections were reacted with rabbit anti-POMC antibody (1:400; lot \#01181-3, Phoenix Pharmaceuticals) or rabbit anti-c-Fos antibody (1:200; produce \#PC38, EMD Chemicals) 
A

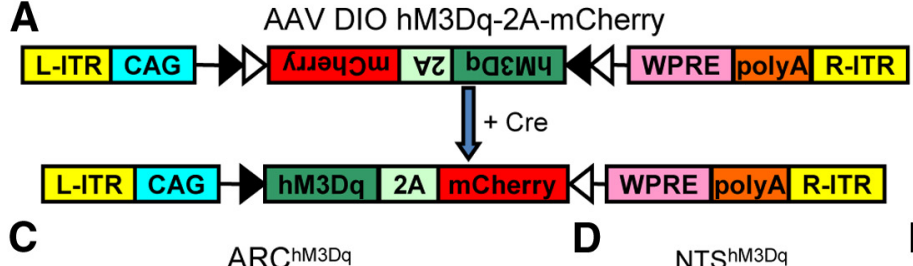

B

AAV DIO mCherry

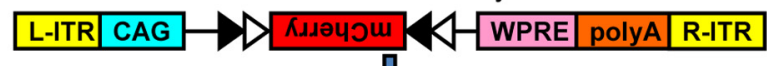

$\int \sqrt{ }+\mathrm{Cre}$
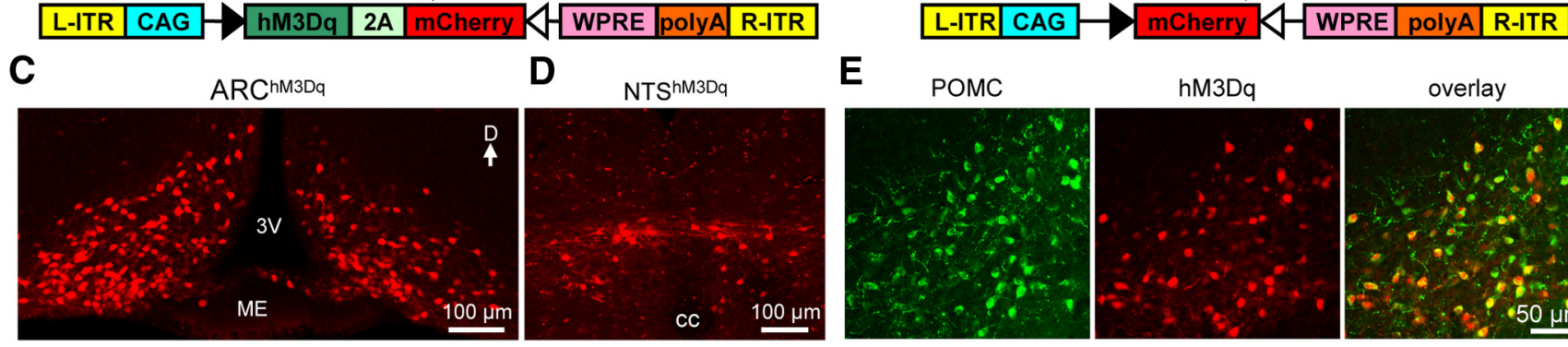

D NTShM3Da

E

$\mathrm{hM} 3 \mathrm{Dq}$
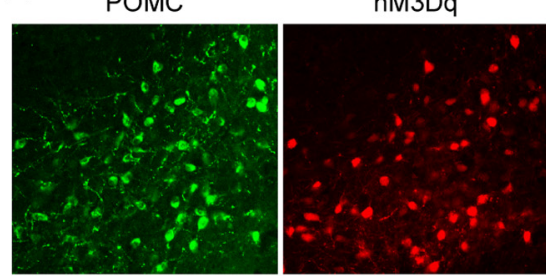

overlay

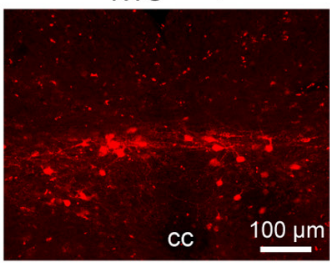

G
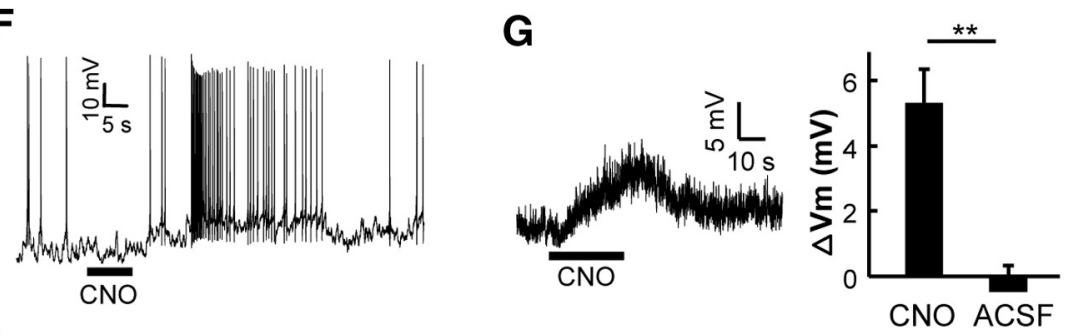

$\mathbf{H}$

I
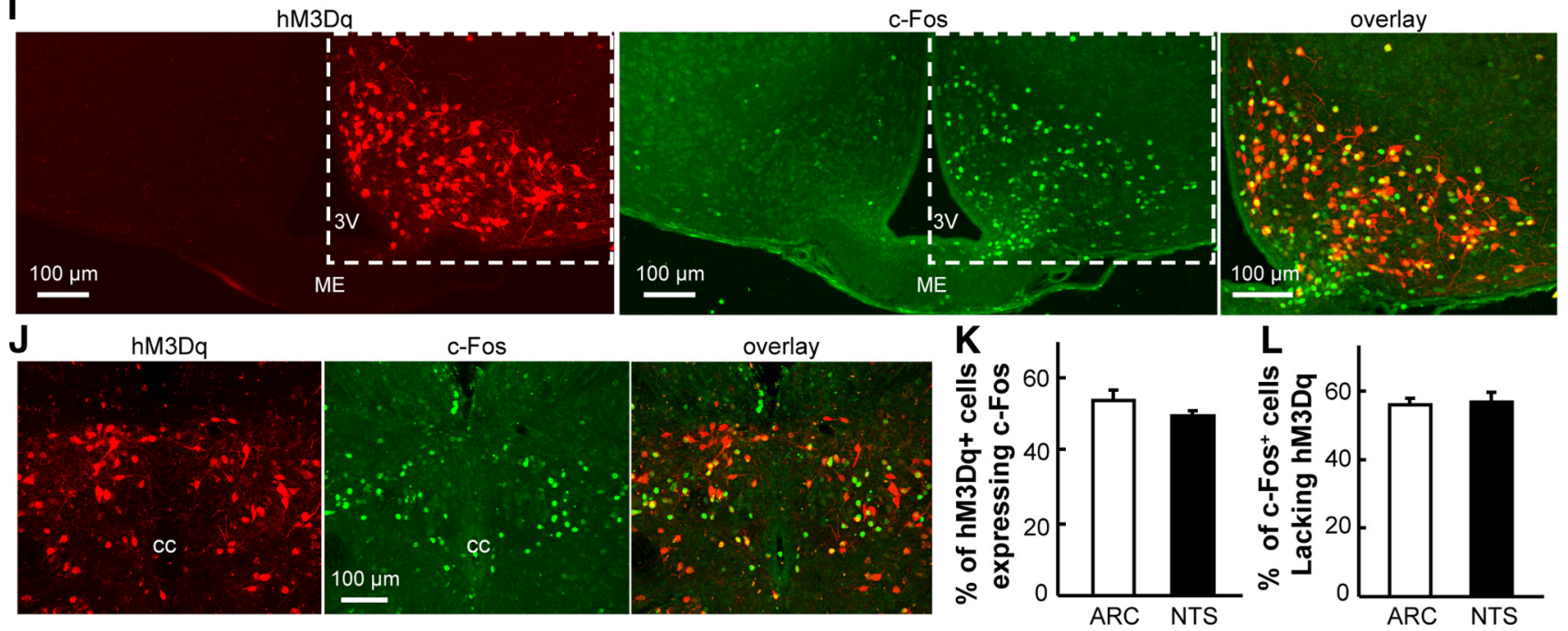

Figure 1. Selective activation of POMC neurons in the ARC or NTS using DREADD technology. $\boldsymbol{A}, \boldsymbol{B}$, Designs for AAV DI0 hM3Dq-2A-mCherry $(\boldsymbol{A})$ and AAV DI0 mCherry $(\boldsymbol{B})$ vectors. L-ITR, Left inverted terminal repeat; CAG, CMV enhancer/chicken $\beta$-actin promoter; WPRE, woodchuck hepatitis virus posttranscriptional regulatory element; and R-ITR, right inverted terminal repeat. $C$, Stereotaxic infusion of AAV DIO hM3Dq-2A-mCherry vectors into the ARC of POMC-Cre mice labels neurons in the bilateral ARC. 3V, Third ventricle; ME, median eminence; and D, dorsal. $\boldsymbol{D}$, Vector injection into the medulla labels a population of neurons in the NTS. cc, Central canal. $\boldsymbol{E}$, Selective expression of hM3Dq/mCherry (red) in POMC-immunopositive neurons (green) in the ARC. $\boldsymbol{F}$, Whole-cell current-clamp recording reveals that an $\mathrm{hM} 3 \mathrm{Dq} / \mathrm{mCherry}{ }^{+}$POMC neuron in the ARC was excited by pressure injection of hM3Dq receptor ligand CNO (horizontal bar). G, Raw recording trace of a single cell and group data show that CNO remains effective in depolarizing hM3Dq/mCherry ${ }^{+}$POMC neurons in the ARC in the presence of tetrodotoxin. Error bars indicate mean + SEM. $\boldsymbol{H}, \mathrm{CNO}$ evokes vigorous firing of action currents from $\mathrm{hM} 3 \mathrm{Dq} / \mathrm{mCherry}{ }^{+} \mathrm{POMC}$ neurons in the NTS. The right panel shows the average peristimulus time histogram of spike firing frequency of five NTS POMC neurons. I, After unilateral expression of hM3Dq (red) in the ARC, CNO injection ( $1 \mathrm{mg} / \mathrm{kg}$, i.p.) induces c-Fos expression (green) in the ipsilateral but not the contralateral ARC. Right panel shows the overlay of mCherry signals and POMC immunoreactivity within the dashed rectangle area in the two left panels. J, c-Fos immunostaining confirms that CNO activates NTS neurons in vivo. $\boldsymbol{K}$, In both the ARC and NTS, approximately half of the hM3Dq-expressing POMC neurons express c-Fos in response to a single injection of CNO. L, More than half of c-Fos ${ }^{+}$neurons lack clear $\mathrm{hM} 3 \mathrm{Dq} / \mathrm{mCherry}$ expression.

overnight at $4^{\circ} \mathrm{C}$ and then incubated with Cy2-conjugated secondary antibody (1:500, lot \#103581, Jackson ImmunoResearch) overnight at $4^{\circ} \mathrm{C}$. Fluorescent images were acquired with a confocal microscope (DigitalEclipse A1, Nikon) and processed with Adobe Photoshop. Cell numbers were counted manually under an epifluorescence microscope.

Electrophysiological recordings. The method of electrophysiological recording from brain slices has been described in detail previously (Ren et al., 2011). Briefly, adult mice were deeply anesthetized and decapitated. Brain sections were cut with a Vibratome (model \#VT1000S, Leica) in ice-cold, oxygenated artificial CSF (aCSF) containing $125 \mathrm{~mm} \mathrm{NaCl}, 2$ mм $\mathrm{CaCl}_{2}, 2.5 \mathrm{~mm} \mathrm{KCl}, 1.3 \mathrm{~mm} \mathrm{MgCl}_{2}, 1.3 \mathrm{~mm} \mathrm{NaH}_{2} \mathrm{PO}_{4}, 1.3 \mathrm{~mm} \mathrm{Na}-$ ascorbate, $0.6 \mathrm{~mm}$ Na-pyruvate, $25 \mathrm{~mm} \mathrm{NaHCO}_{3}$, and $20 \mathrm{~mm}$ glucose, and then incubated in warm oxygenated $\mathrm{aCSF}\left(34^{\circ} \mathrm{C}\right)$ for $1 \mathrm{~h}$. Brain slices were transferred into the recording chamber and superfused $(2 \mathrm{ml} / \mathrm{min})$ with oxygenated aCSF at room temperature $\left(22-25^{\circ} \mathrm{C}\right)$. Whole-cell patch recordings or cell-attached patch recordings were performed with a computer-controlled amplifier (MultiClamp 700B, Molecular Devices). Whole-cell patch-clamp recording pipettes (4-7 M $\Omega$ ) were backfilled with internal solution containing the following: $130 \mathrm{~mm} \mathrm{~K}$-gluconate, 10 mм HEPES, 0.6 mм EGTA, 5 mм KCl, 3 mм Na2ATP, 0.3 mм Na3GTP, 

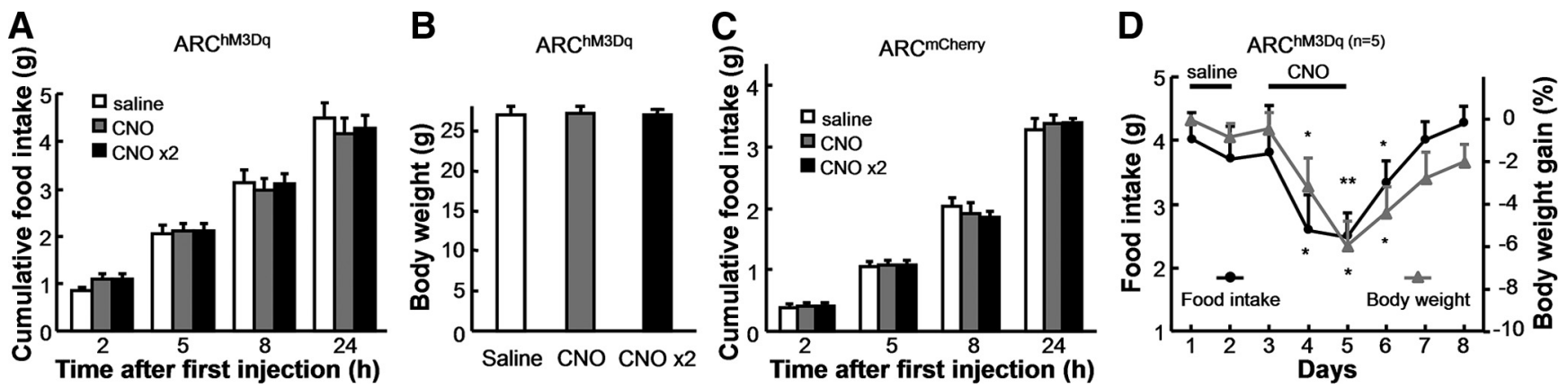

Figure 2. Chronic but not acute activation of ARC POMC neurons inhibits feeding and body weight. $A$, Neither a single CNO injection (CNO) nor two injections at $5 \mathrm{~h}$ intervals (CNO $\times 2$ ) affect food intake of ARC ${ }^{\mathrm{CM} 3 \mathrm{Dq}}$ mice. $\boldsymbol{B}$, Acute CNO administration does not affect the body weight of ARC ${ }^{\mathrm{CM} 3 \mathrm{Dq}}$ mice. C, CNO has no effect on the food intake of ARC ${ }^{\text {mCherry }}$ control mice. D, Multiple CNO injections for $3 \mathrm{~d}$ suppress the food intake and reduce the body weight of $\mathrm{ARC}{ }^{\mathrm{hM} 3 \mathrm{Dq}}$ mice. Significant effects were observed $1 \mathrm{~d}$ after chronic $\mathrm{CN} 0$ administration $\left({ }^{*} p<0.05 ;{ }^{* *} p<0.01\right.$; paired $t$ test between saline control and CNO injections; $n=5$ ARC ${ }^{\mathrm{hMBDa}}$ mice). Asterisks above the lines indicate significant effects on food intake and those below indicate effects on body weight. Error bars indicate mean + SEM.

$4 \mathrm{~mm} \mathrm{MgCl}$, and $10 \mathrm{~mm}$ Na2phosphocreatine, $\mathrm{pH}$ 7.2-7.4. Series resistance $(20-30 \mathrm{M} \Omega)$ was compensated for in all whole-cell recordings. The pipettes for cell-attached recording $(3-4 \mathrm{M} \Omega)$ contained bath solution and the seal resistance was $\sim 200 \mathrm{M} \Omega$. hM3Dq/mCherry ${ }^{+}$POMC neu- $^{-}$ rons were targeted in the ARC or NTS under the visual guidance of red fluorescent signals using an upright microscope (Examiner Z1, Zeiss). CNO dissolved in aCSF was released to the recording area with a small pressure using an 8-channel drug-delivery system (MPS-1, Inbio Life Science Instrument). Traces were low-pass filtered at $2.6 \mathrm{kHz}$ and digitized at $10 \mathrm{kHz}$ (DigiData 1440, Molecular Devices).

Statistical analysis. Data analysis was performed with MATLAB (MathWorks). The $t$ test and ANOVA were used to determine the significance of differences between groups, and $p<0.05$ was considered as significant. Group data are represented as means + SEM in the figures.

\section{Results}

Selective activation of POMC neurons in the ARC or NTS

To activate POMC neurons selectively, AAV vectors were used to express the hM3Dq receptor, which has a high affinity for the pharmacologically inert ligand $\mathrm{CNO}$ but not endogenous neurotransmitters (Alexander et al., 2009). The hM3Dq coding sequence was packaged into a Cre-recombinase-dependent AAV vector that enabled bicistronic expression of the red fluorescent protein mCherry (AAV DIO hM3Dq-2A-mCherry; Fig. 1A). AAV DIO mCherry vectors were used as the control (Fig. 1B). Two weeks after stereotaxic infusion of AAV DIO hM3Dq-2AmCherry viral vectors into the ARC or the NTS of POMC-Cre mice, mCherry expression was detected exclusively in either of these two brain areas (Fig. 1C,D). Red fluorescent mCherry signals were colocalized with POMC immunoreactivity in the majority $(>95 \%)$ of the neurons in the ARC (Fig. 1E). The efficiency of $\mathrm{hM} 3 \mathrm{Dq} / \mathrm{mCherry}$ expression was comparable among POMC neurons in the ARC and NTS. Using labeling of bicistronically expressed mCherry as a marker, clear hM3Dq expression was observed in $\sim 70 \%$ of POMC-immunopositive neurons in the entire ARC of ARC ${ }^{\mathrm{hM} 3 \mathrm{Dq}}$ mice $\left(2050 \pm 254 \mathrm{hM} 3 \mathrm{Dq} / \mathrm{mCherry}^{+}\right.$ neurons of a total of $\sim 3000 \mathrm{POMC}^{+}$neurons; mean $\pm \mathrm{SEM} ; n=$ 9 mice). Similarly, $\sim 77 \%$ of POMC neurons in the NTS expressed hM3Dq $\left(311 \pm 34 \mathrm{hM} 3 \mathrm{Dq} / \mathrm{mCherry}^{+}\right.$cells of the reported total of $\sim 400$ POMC neurons; $n=11 \mathrm{NTS}^{\mathrm{hM} 3 \mathrm{Dq}}$ mice) (Cone, 2005).

To determine whether CNO could activate POMC neurons, targeted whole-cell recordings were made from hM3Dq/ mCherry ${ }^{+}$POMC neurons in the ARC of brain slices. CNO administration $(10 \mu \mathrm{M})$ depolarized these cells significantly, from $-57.1 \pm 2.0 \mathrm{mV}$ to $-45.7 \pm 2.4 \mathrm{mV}(p<0.01$; paired $t$ test; $n=$
5 cells) and increased the firing frequency of action potentials from $0.04 \pm 0.04 \mathrm{~Hz}$ to $1.30 \pm 0.30 \mathrm{~Hz}(p<0.05$; paired $t$ test; $n=5$ cells; Fig. $1 F)$. CNO, but not the aCSF control, remained capable of depolarizing ARC POMC neurons in the presence of the sodium channel blocker tetrodotoxin $\left(1 \mu \mathrm{M}\right.$; ${ }^{* *} p<0.01$; $t$ test between $\mathrm{CNO}$ and aCSF control; $n=5$ cells; Fig. $1 G)$, suggesting that $\mathrm{CNO}$ excited ARC POMC neurons directly without synaptic input. Similarly, cell-attached recordings demonstrated that CNO activated $\mathrm{hM} 3 \mathrm{Dq} / \mathrm{mCherry}^{+}$POMC neurons effectively in the NTS (action potential firing frequency $=1.5 \pm 0.9 \mathrm{~Hz}$ before $\mathrm{CNO}$ and $3.3 \pm 1.1 \mathrm{~Hz}$ during $\mathrm{CNO} ; p<0.05$; paired $t$ test; $n=$ 5 cells; Fig. $1 H)$.

The pattern of neuronal activation was then examined in vivo. CNO (1 mg/kg, i.p.) was injected into POMC-Cre mice with unilateral hM3Dq/mCherry expression in the ARC and c-Fos expression was used as an indicator of neuronal activity. The number of c-Fos ${ }^{+}$cells $(\sim 1000)$ in the ipsilateral ARC was approximately ninefold that in the contralateral side (Fig. 1I). In the NTS, the number of $\mathrm{c}-\mathrm{Fos}^{+}$neurons in NTS ${ }^{\text {hM3Dq }}$ mice $(\sim 300$ cells) was similar, at $\sim 9$ times of that in NTS ${ }^{\text {mCherry }}$ control mice $(n=5$ mice of either group; Fig. $1 J)$. In both the ARC and NTS, the overall distribution pattern of c-Fos ${ }^{+}$cells resembled that of hM3Dq/mCherry ${ }^{+}$POMC cells. By examining the dual-color fluorescent signals of a total of $7678 \mathrm{hM} 3 \mathrm{Dq} / \mathrm{mCherry}^{+}$neurons from the ARC of six ARC ${ }^{\mathrm{hM} 3 \mathrm{Dq}}$ mice and 1392 cells from the NTS of five NTS ${ }^{\text {hM3Dq }}$ mice, approximately half of hM3Dq/ $\mathrm{mCherry}^{+}$neurons were found to be c-Fos positive in these two nuclei $(53.9 \pm 2.6 \%$ in the ARC and $49.7 \pm 1.1 \%$ in the NTS; Fig. $1 K)$. However, in both areas, more than half of the $\mathrm{c}-F o s^{+}$neurons lacked clear hM3Dq/mCherry expression $(55.7 \pm 1.9 \%$ in the ARC and $56.4 \pm 3 \%$ in the NTS; Fig. $1 L$ ), likely because CNO triggered c-Fos expression in nearby non-POMC neurons through synaptic connections from POMC neurons.

\section{Acute feeding suppression by activating POMC neurons in the NTS but not the ARC}

After establishing the validity of pharmacogenetic activation of POMC neurons, the effect of CNO injection on food intake and body weight of $\mathrm{ARC} \mathrm{hM3Dq}^{\mathrm{h}}$ mice that expressed $\mathrm{hM} 3 \mathrm{Dq}$ in the bilateral ARC was analyzed (Fig. $2 A, B ; n=9$ mice). Saline injection into $\mathrm{ARC}^{\mathrm{hM} 3 \mathrm{Dq}}$ mice was used as the self-control (Fig. $2 A$ ) and $\mathrm{CNO}$ injection into ARC ${ }^{\text {mCherry }}$ mice was used as an additional control (Fig. $2 C ; n=8$ mice). A two-way ANOVA was conducted to compare the effect of CNO injections and the du- 
A

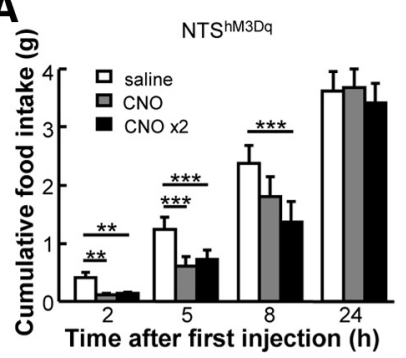

E

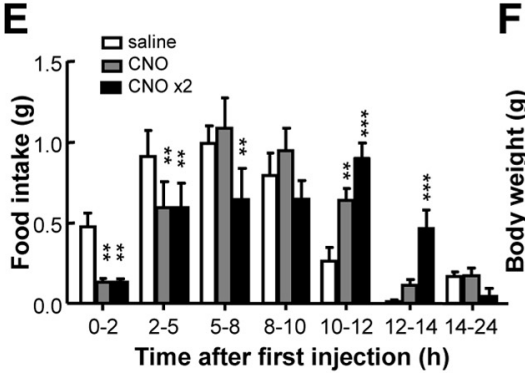

B

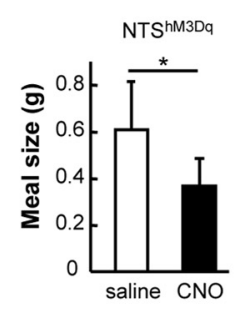

F

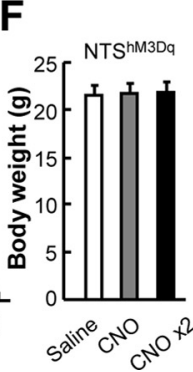

C

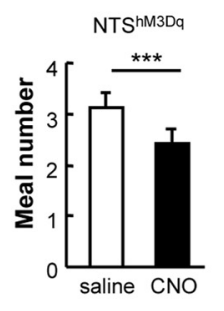

G

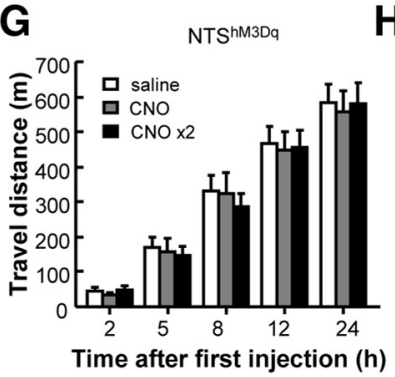

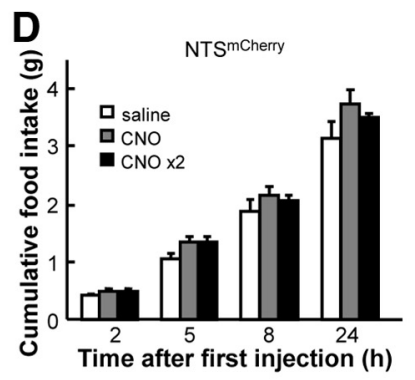

H

Figure 3. Activating POMC neurons in the NTS suppresses feeding behavior immediately. $A$, Amount of food intake at different time points after first CNO injection into NTS ${ }^{\text {hMBDa }}$ mice. Food intake is significantly reduced within $2-5 \mathrm{~h}$ of the first CNO injection. A second CNO injection $5 \mathrm{~h}$ after the initial injection significantly inhibits food intake for an additional 3 h. B, C, Acute CNO administration reduces the meal size $(\boldsymbol{B})$ and meal number $(\boldsymbol{C})$ of NTS ${ }^{\mathrm{hM} 3 \mathrm{Dq}}$ mice significantly. $\boldsymbol{D}$, CNO does not affect the food intake of NTS ${ }^{\mathrm{m} C h e r r y}$ mice. $\boldsymbol{E}$, Food intake within different time periods after the first CNO injection. $F$, No effect by acute CNO administration on the body weight of NTS ${ }^{\mathrm{hM} 3 \mathrm{Dq}}$ mice. $\boldsymbol{G}$, CNO administration does not change the level of locomotor activity within different time periods after the first CNO injection. $\boldsymbol{H}$, Effects of chronic CNO application on the daily food intake and body weight of NTS ${ }^{\mathrm{hM} 3 \mathrm{q}}$ mice $\left({ }^{*} p<0.05\right.$; ${ }^{* *} p<0.01 ;$ paired $t$ test between days of saline control and those of (NO injection; $n=5$ mice). Asterisks above the lines indicate significant effects on food intake and those below indicate effects on body weight. Error bars indicate mean + SEM.

ration after initial CNO injections. There was no significant effect on food intake after either a single $\mathrm{CNO}$ injection or 2 injections in 5 h intervals (ANOVA: drug effect $F_{(2,96)}=0.092, p=0.91 n=$ 9 mice; Fig. $2 A$ ). The duration was the only determining factor on food intake $\left(F_{(3,96)}=157.7, p<0.001\right)$, and acute CNO administrations did not alter the body weight of $\mathrm{ARC}^{\mathrm{hM} 3 \mathrm{Dq}}$ mice $(p=$ 0.96 and 0.95 ; paired $t$ test between saline and $\mathrm{CNO}$ and that between saline and $\mathrm{CNO} \times 2$, respectively; $n=9$ mice; Fig. $2 B$ ). Similar observations were made for ARC ${ }^{\text {mCherry }}$ control mice (ANOVA: drug effect $F_{(2,84)}=0.38, p=0.69 ; n=8$ mice; Fig. $2 C)$. However, the amount of daily food intake and body weight

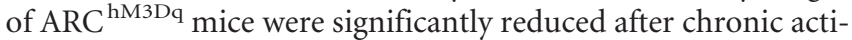
vation of ARC POMC neurons with consecutive $\mathrm{CNO}$ injections for $3 \mathrm{~d}$ ( $5 \mathrm{~h}$ interval between injections; ANOVA on body weight of ARC ${ }^{\text {hMBDq }}$ mice: $\operatorname{drug} F_{(2,32)}=5.5, p<0.01 ;$ time $F_{(2,32)}=1.4$, $p=0.25$; interaction between drug and time $F_{(3,32)}=5.23, p<$ 0.01 ; ANOVA on food intake of ARC ${ }^{\mathrm{hM} 3 \mathrm{Dq}}$ mice: $\operatorname{drug} F_{(2,32)}=$ $3.5, p<0.05$; time $F_{(2,32)}=0.27, p=0.76$; interaction between drug and time $F_{(3,32)}=2.16 ; p=0.11 ; n=5$ mice; Fig. $\left.2 D\right)$. As a control, chronic CNO injection did not change the food intake nor body weight of ARC ${ }^{\text {mCherry }}$ mice significantly (ANOVA on bodyweight of ARC ${ }^{\text {mCherry }}$ control mice: $\operatorname{drug} F_{(2,32)}=0.07, p=$ 0.93 ; time $F_{(2,32)}=0.10, p=0.91$; interaction between drug and time $F_{(3,32)}=0.36 ; p=0.79$; ANOVA on food intake of $\mathrm{ARC}^{\text {mCherry }}$ control mice: $\operatorname{drug} F_{(2,32)}=0.12, p=0.89$; time $F_{(2,32)}=1.68, p=0.20$; interaction between drug and time $F_{(3,32)}=0.52, p=0.67 ; n=5$ mice). These observations suggest that long-term but not acute activation of ARC POMC neurons suppresses animal feeding behavior.

Interestingly, acute activation of NTS POMC neurons produced immediate inhibition of feeding behavior. Within the first $2 \mathrm{~h}$ of CNO injection, NTS ${ }^{\mathrm{hM} 3 \mathrm{Dq}}$ mice exhibited an $\sim 70 \%$ decrease in food intake ( $n=8$ mice; Fig. $3 A$ ). A significant inhibitory effect on the amount of accumulative food consumption lasted for up to $5 \mathrm{~h}$ (ANOVA: $\operatorname{drug} F_{(2,84)}=5.05, p<0.01$; time $F_{(3,84)}=97.52, p<0.001$; Bonferroni post hoc tests after ANOVA: ${ }^{* *} p<0.01 ;{ }^{* *} p<0.001 ; n=8$ mice; Fig. $\left.3 A\right)$. Meal number and meal size were also reduced $\left({ }^{\star} p=0.034 ;{ }^{* * *} p<0.001\right.$; paired $t$ test; $n=8$ mice; Fig. $3 B, C$ ). The effective duration of $\mathrm{CNO}$ is consistent with an earlier study on the effective duration of in vivo CNO application (Alexander et al., 2009). CNO injections into NTS ${ }^{\text {mCherry }}$ mice given as a control did not affect food intake (ANOVA: drug $F_{(2,60)}=3.1, p=0.06$; time $F_{(3,60)}=260.8, p<$ 0.001 ; interaction between drug and time $F_{(6,60)}=1.2, p=0.35$; $n=6$ mice; Fig. $3 D$ ). A second $\mathrm{CNO}$ injection $5 \mathrm{~h}$ after the initial injection prolonged the inhibition for at least an additional $3 \mathrm{~h}$ $\left({ }^{* * *} p<0.001\right.$; post hoc tests after ANOVA; $n=8$ mice; Fig. $3 A$ ), but NTS ${ }^{\mathrm{hM} 3 \mathrm{Dq}}$ mice compensated for the inhibited food intake during the next few hours (ANOVA: interaction between drug and time $F_{(12,147)}=4.13, p<0.001$; Bonferroni post hoc tests after ANOVA: ${ }^{\star \star} p<0.01 ;{ }^{* *} p<0.001 ; n=8$ mice; Fig. $\left.3 E\right)$. This led to an apparently normal amount of cumulative food intake on a daily basis and normal body weights for NTS ${ }^{\text {hM3Dq }}$ mice $(p=$ 0.84 and 0.81 for paired $t$ test between saline and $\mathrm{CNO}$ and that between saline and $\mathrm{CNO} \times 2$, respectively; $n=8$ mice; Fig. $3 A, F)$. Locomotor activity was measured to determine whether the suppression of food intake was associated with a reduction in activity or arousal levels. CNO injections did not change the locomotor activity of $\mathrm{NTS}^{\mathrm{hM} 3 \mathrm{Dq}}$ mice (2-way ANOVA: drug $F_{(2,75)}=0.22, p=0.80$; time $F_{(4,75)}=73.4, p<0.001$; interaction between drug and time $F_{(8,75)}=0.1 ; p=0.99 ; n=6$ mice; Fig. $3 G)$, suggesting that acute activation of NTS POMC neurons did not change motor ability nor arousal levels.

When NTS ${ }^{\text {hM3Dq }}$ mice were given chronic stimulation with multiple $\mathrm{CNO}$ injections for $3 \mathrm{~d}$, daily food intakes and body weights were decreased significantly for the first day but then rebounded during the following days (ANOVA on food intake: $\operatorname{drug} F_{(2,32)}=11.15, p<0.001 ;$ time $F_{(2,32)}=5.75 ; p<0.01$; 
A
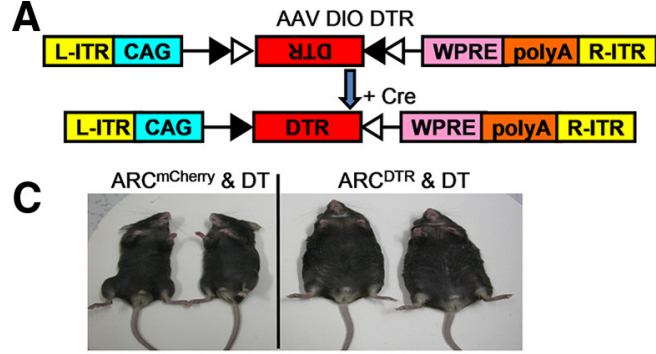

B

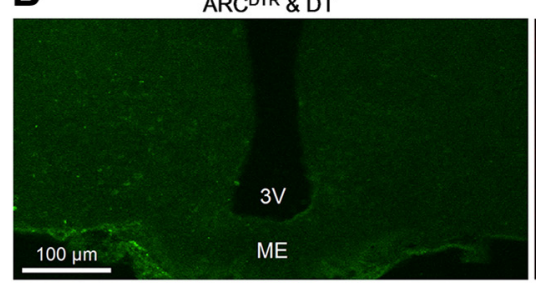

NTS DTR \& DT

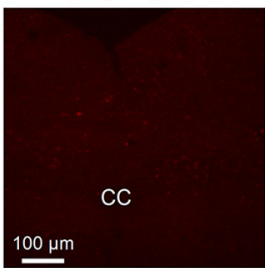

D

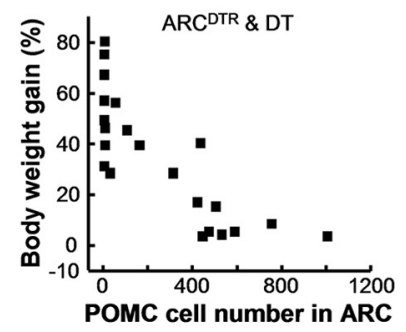

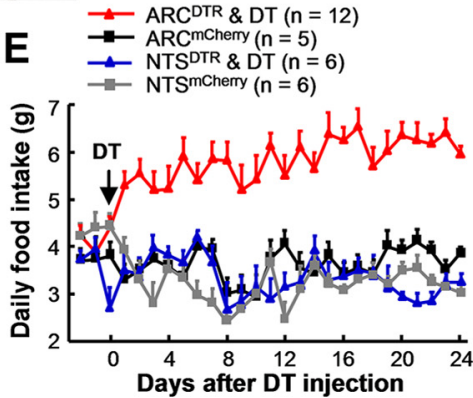

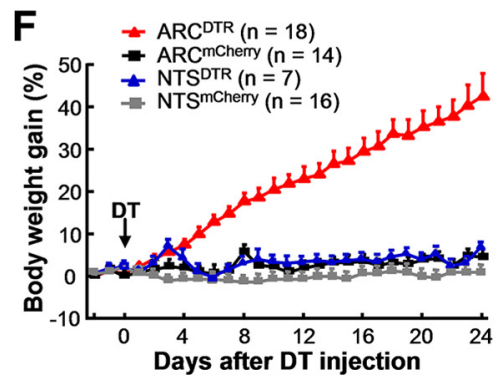

Figure 4. Ablating POMC neurons in the ARC but not the NTS causes obesity and hyperphagia. $A$, Design for AAV DIO DTR vectors. $\boldsymbol{B}$, Images illustrating that DT injections eliminate POMC neurons in the ARC of ARC ${ }^{\text {DTR }}$ mice (left) and the NTS of NTS ${ }^{\text {DTR }}$ mice (right). POMC immunostaining (green) was performed to confirm the lesion effect in the ARC. AAV DIO mCherry was injected into NTS ${ }^{\text {DTR }}$ mice to confirm the killing of POMC neurons in the NTS by mCherry labeling. C, After DT injections, ARC ${ }^{D T R}$ mice but not control ARC ${ }^{\text {mCherry }}$ mice display clear obesity. D, The effect of body weight gain is negatively correlated with the number of remaining POMC neurons in the entire ARC. Each square represents data from a single mouse. E, DT injections increase daily food intake significantly for ARC ${ }^{\text {DTR }}$ mice but not NTS ${ }^{\text {DTR }}$ mice. $F$, Plots of body weight gain for mice with ablations of POMC neurons in the ARC or the NTS. Eliminating POMC neurons in the ARC but not the NTS results in significant weight gain. Error bars indicate mean + SEM.

interaction between drug and time $F_{(3,32)}=2.87 ; p=0.05$; ANOVA on bodyweight: $\operatorname{drug} F_{(2,32)}=15.0, p<0.001$; time $F_{(2,32)}=0.59, p=0.56$; interaction between drug and time $F_{(3,32)}=0.68 ; p=0.57 ; n=5$ mice; Fig. $\left.3 H\right)$. In contrast, the food intakes and body weights of NTS ${ }^{\text {mCherry }}$ control mice were not affected by chronic CNO application (ANOVA on food intake: $\operatorname{drug} F_{(2,32)}=0.41 ; p=0.67$; time $F_{(2,32)}=1.79 ; p=0.18$; interaction between drug and time $F_{(3,32)}=0.71 ; p=0.55$; ANOVA on body weight: $\operatorname{drug} F_{(2,32)}=0.76, p=0.48$; time $F_{(2,32)}=0.30$,

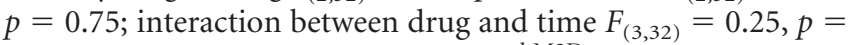
$0.86 ; n=5$ mice). The data from NTS ${ }^{\mathrm{hM} 3 \mathrm{Dq}}$ mice thus indicate that the activity of NTS POMC neurons is responsible for acute but not chronic inhibition of feeding behavior.

\section{Selective ablation of POMC neurons in the ARC but not the NTS causes obesity}

The necessity of ARC or NTS POMC neurons in regulating energy homeostasis was investigated by ablating these two neuron populations separately. AAV DIO DTR viral vectors were infused into the ARC or the NTS of POMC-Cre mice (ARC ${ }^{\text {DTR }}$ and NTS $^{\text {DTR }}$ mice, respectively) to express DTR in POMC neurons (Fig. 4A). Figure $4 B$, left, shows the representative effect of killing ARC POMC neurons after an injection of DT ( $50 \mu \mathrm{g} / \mathrm{kg}$, i.p.) into an ARC $^{\text {DTR }}$ mouse. By counting the number of neurons with POMC immunoreactivity in the ARC, DT injection was found to kill $60-100 \%$ of POMC neurons in the ARC ( $n=22$ mice). Due to the difficulty in labeling NTS POMC neurons with immunostaining methods (Bronstein et al., 1992; Huo et al., 2006), AAV DIO mCherry vectors was delivered to label POMC neurons in the NTS after behavioral tests. DT reduced the number of mCherry ${ }^{+}$neurons drastically in the NTS of NTS ${ }^{\text {DTR }}$ mice (Fig. $4 B$, right), whereas it did not induce any apparent change in the distribution pattern of $\mathrm{mCherry}^{+}$neurons in NTS mCherry control mice (data not shown). Therefore, POMC neurons in either the ARC or NTS could be separately ablated by taking the approach of expressing DTR with Credependent AAV vectors.

Ablation of POMC neurons in the ARC resulted in obesity in a substantial number of ARC ${ }^{\text {DTR }}$ mice (Fig. $4 C$ ). The extent of body weight gain was negatively correlated with the number of surviving POMC neurons (Pearson's correlation coefficient $r=$ $-0.81 ; p<0.001)$, and it appears that $\sim 500$ cells in the ARC were sufficient to maintain normal body weight (Fig. 4D). The $\mathrm{ARC}^{\mathrm{DTR}}$ mice with $<500$ POMC neurons in the ARC consumed significantly more food than the ARC ${ }^{\text {mCherry }}$ control mice (ANOVA: lesion $F_{(3,675)}=40.14, p<0.001$; time $F_{(26,675)}=$ $1.523, p=0.056$; interaction between lesion and time $F_{(78,675)}=$ 3.148, $p<0.001$; Bonferroni post hoc tests after two-way ANOVA: $p<0.01$ for day 1 and $p<0.001$ thereafter between $\mathrm{ARC}^{\mathrm{DTR}}$ and ARC ${ }^{\text {mCherry }}$ mice; Fig. $4 E$ ). Lesions of ARC POMC neurons also resulted in a steady increase in body weight (ANOVA: lesion $F_{(3,1377)}=35.23, p<0.001$; time $F_{(26,1377)}=$ $26.91, p<0.001$; interaction between lesion and time $F_{(78,1377)}=$ 25.93, $p<0.001$. Bonferroni post hoc tests after two-way ANOVA: $p<0.01$ for days 6 and 7 and $p<0.001$ after day 7 between ARC ${ }^{\text {DTR }}$ and ARC ${ }^{\text {mCherry }}$ mice; Fig. $4 F$ ).

In addition to increased food intake, energy expenditure was reduced in the obese ARC ${ }^{\mathrm{DTR}}$ mice. Their locomotor activity was significantly lower than that of ARC ${ }^{\text {mCherry }}$ control mice during the dark phase of the light cycles (ANOVA: lesion $F_{(1,28)}=130, p<$ 0.001 ; dark/light phase $F_{(1,28)}=37.3, p<0.001$; interaction between lesion and dark/light phase $F_{(1,28)}=20.8, p<0.001$; Bonferroni post hoc tests after two-way ANOVA: $p<0.001$ for tests between $\mathrm{ARC}^{\mathrm{DTR}}$ and $\mathrm{ARC}^{\text {mCherry }}$ mice for dark phase; $p>0.05$ for light phase; $n=8$ mice for each group; Fig. $5 A$ ). Consistently, the oxygen metabolism of DT-treated ARC ${ }^{\text {DTR }}$ mice was lower than that of ARC ${ }^{\text {mCherry }}$ control mice $\left({ }^{* *} p<0.001\right.$; between-group $t$ test, Fig. 5B).

The ARC ${ }^{\text {DTR }}$ mice had markedly higher body fat mass and lower lean mass $\left({ }^{* *} p<0.001 ; t\right.$ test between $\mathrm{ARC}^{\mathrm{DTR}}$ and 
ARC ${ }^{\text {mCherry }}$ mice; Fig. $6 A$ ) and exhibited a broad spectrum of metabolic and endocrine disorders associated with obesity. ARC ${ }^{\text {DTR }}$ mice had significantly higher levels of total serum cholesterol, highdensity lipoprotein cholesterol, and low-density lipoprotein cholesterol serum lipids $\left({ }^{*} p<0.05 ; t\right.$ tests between ARC ${ }^{\text {mCherry }}$ and $\mathrm{ARC}^{\mathrm{DTR}}$ mice injected with DT) but not triglycerides $(p=0.41 ; t$ test; Fig. $6 B$ ). These mice showed fasting hyperglycemia and impaired glucose tolerance (ANOVA: lesion $F_{(3,132)}=21.1, p<0.001$; time $F_{(5,132)}=21.5, p<0.001$; interaction between lesion and time $F_{(15,132)}=1.4, p=0.17$. Bonferroni post hoc tests after two-way ANOVA: $p>0.05$ at $0 \mathrm{~min} ; p<0.01$ at $15 \mathrm{~min} ; p<0.001$ during 30-120 min for comparison between $\mathrm{ARC}^{\mathrm{DTR}}$ and ARC ${ }^{\text {mCherry }}$ mice; Fig. 6C). Moreover, ablating ARC POMC neurons reduced plasma corticosterone levels significantly $\left({ }^{*} p<0.05\right.$; $t$ test between $\mathrm{ARC}^{\mathrm{DTR}}$ and $\mathrm{ARC}^{\text {mCherry }}$ mice; Fig. $6 D$ ). Similar DT injection into 16 NTS $^{\text {DTR }}$ mice was performed and complete ablation was observed in seven of them. The body weight of these 16 NTS $^{\text {DTR }}$ mice resembled that of DT-injected NTS ${ }^{\text {mCherry }}$ control mice. Data for the seven completely lesioned animals are shown in Figures 4 and 6. Ablating NTS POMC neurons did not affect food intake (Fig. 4E), body weight (Fig. $4 F$ ), body composition, lipid and glucose metabolism, or corticosterone levels (Fig. 6). Therefore, POMC neurons in the ARC but not in the NTS are necessary for maintaining normal food intake, metabolism, and body weight.

\section{Discussion}

In this study, we examined the behavioral functions of POMC neurons in the ARC and NTS by selectively manipulating these two neuronal populations with pharmacogenetic approaches. Chronic but not acute activation of ARC POMC neurons reduced food intake. Moreover, ablating these neurons resulted in hyperphasia, obesity, and metabolism disorders. In contrast, acute stimulation of NTS POMC neurons rapidly suppressed feeding, but killing these neurons did not produce any obvious changes in feeding behavior or body weight. These results indicate that POMC neurons in the ARC and NTS play different roles in regulating feeding behavior and metabolism. Specifically, our observations are consistent with the model suggesting that the activity of ARC POMC neurons is critical for maintaining long-term energy homeostasis, but that of NTS POMC neurons contributes to short-term feeding control in response to satiety signals.

Previous genetic and pharmacological studies have established the important functions of POMC signals in the regulation of feeding behavior and energy homeostasis (Yaswen et al., 1999; McMinn et al., 2000; Challis et al., 2004). However, it has been challenging to determine the functions of separate populations of POMC neurons in the ARC and NTS of adult animals. POMC is expressed dynamically in numerous brain areas in the developing mouse brain (Padilla et al., 2010; Padilla et al., 2012). Therefore, knocking out the POMC gene may alter neural circuits that are not directly related to feeding regulation in the adult
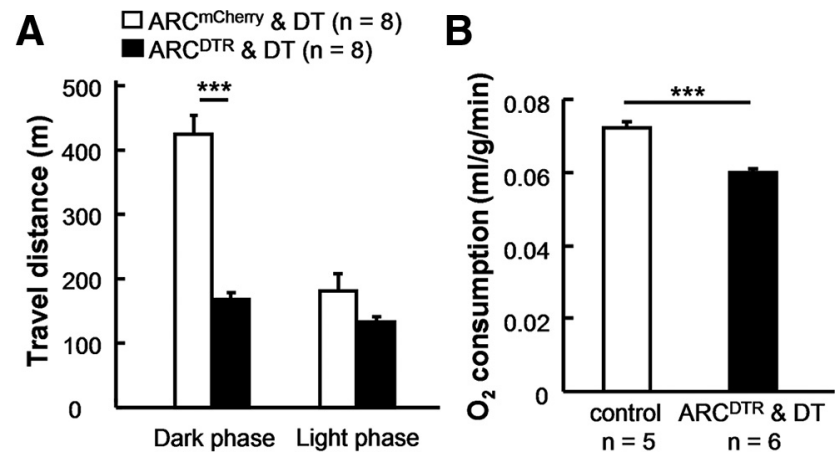

Figure 5. Ablating POMC neurons in the ARC reduces locomotor activity and energy expenditure. $\boldsymbol{A}$, DT administration reduces the locomotor activity level of ARC ${ }^{\text {DTR }}$ mice significantly during the dark but not the light phases. $B$, DT lesion of ARC POMC neurons significantly reduces animal oxygen consumption in a metabolic cage. Error bars indicate mean + SEM.
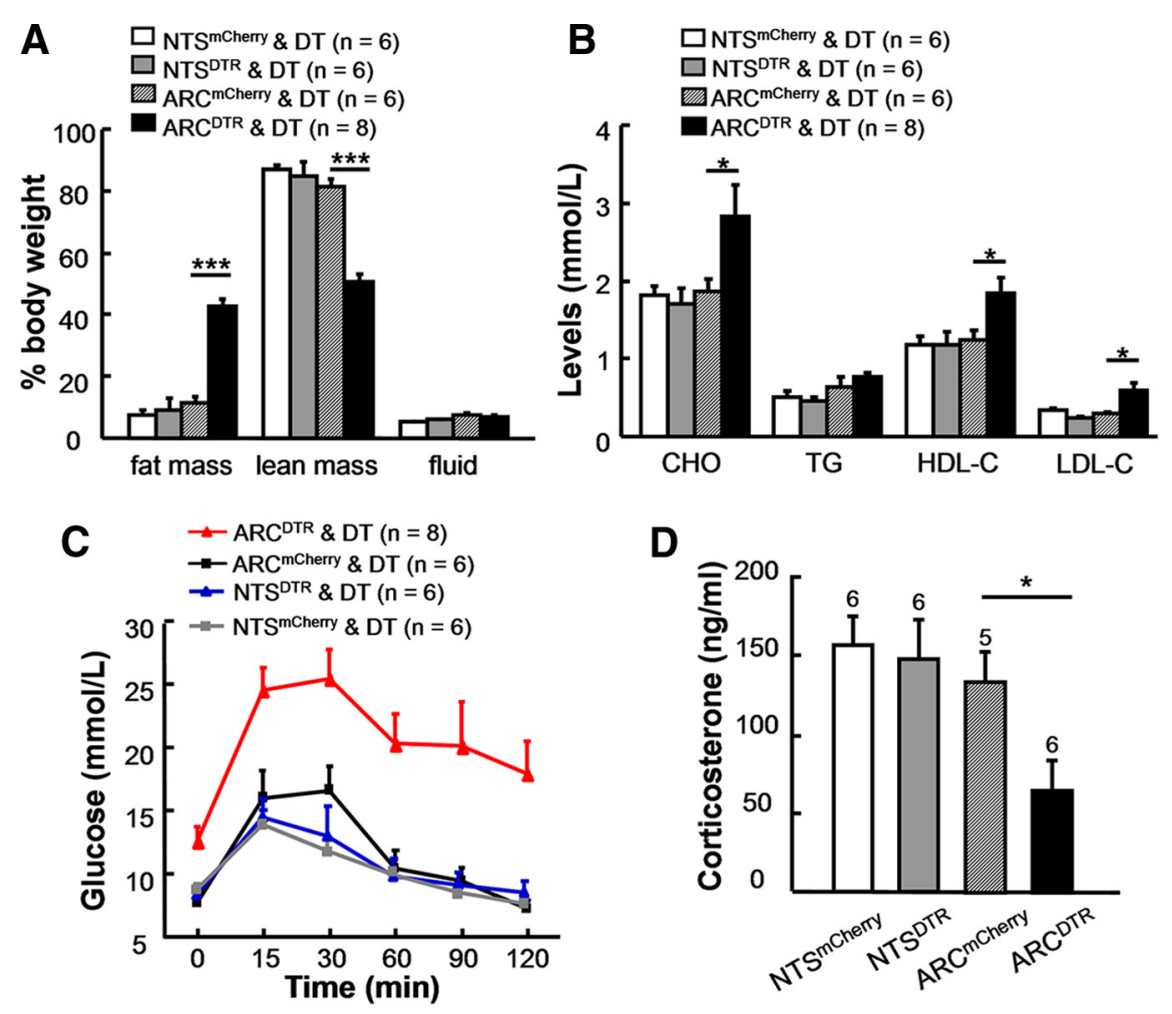

Figure 6. The effects of ablating POMC neurons on metabolism. $\boldsymbol{A}$, Ablating POMC neurons in the ARC but not the NTS increase the percentage of fat mass and reduces the percentage of lean mass significantly 1 month after DT treatment. $B, 0$ bese ARC ${ }^{\text {DTR }}$ and DT mice exhibit significantly higher levels of serum total cholesterol ( $\mathrm{CHO}$ ), high-density lipoprotein cholesterol (HDL-C), and low-density lipoprotein cholesterol (LDL-C). The level of triglycerides (TGS) in these mice is comparable to that in control animals. $\boldsymbol{C}$, Ablating POMC neurons in the ARC but not the NTS produces glucose intolerance. $\boldsymbol{D}$, Obese ARC ${ }^{\text {DTR }}$ and DT mice exhibit significantly lower serum corticosterone level. Error bars indicate mean + SEM. brain. Similarly, many non-POMC neurons in the adult may be ablated by taking the traditional approach of crossing POMCCre mouse with the iDTR mouse line. The pharmacogenetic approaches in the present study have several advantages that overcome the technical limits of prior studies. Stereotaxic viral gene delivery into the adult brain avoided the potential off-target effect in transgenic animals that drives gene expression from the time of gestation (Padilla et al., 2012). More importantly, separate manipulations allowed us to probe the behavioral functions of POMC neurons selectively in the ARC and NTS. Finally, activation and lesion facilitated the study of the sufficiency and necessity of adult POMC neurons in behavioral regulation. 
Our results confirm and extend our understanding about the behavioral functions of the central melanocortin system. Consistent with recent optogenetic stimulation of ARC POMC neurons (Aponte et al., 2011), we have shown that feeding suppression was produced only by long-term (over a day) but not acute stimulation (several hours) of these neurons. In addition, we have found that selective lesions of POMC neurons in the ARC but not the NTS resulted in obesity, lower energy expenditure, and numerous metabolic and endocrine disorders that are typically associated with obesity. The behavioral effects of ablating POMC neurons in the ARC alone resembled the obesity phenotype produced by removing POMC neurons in the entire brain (Gropp et al., 2005), indicating that ARC but not NTS POMC neurons are critical for maintaining normal body weight. Selective expression of the leptin receptor in brain POMC neurons increases the activity level of the $\mathrm{db} / \mathrm{db}$ mice that lack functional leptin receptors (Huo et al., 2009). Consistently, we found that ablating POMC neurons in the ARC reduced animal locomotor activity and oxygen consumption, suggesting that these neurons control energy homeostasis by both reducing food intake and increasing energy expenditure. ARC POMC neurons are activated by leptin and glucose (Cowley et al., 2001; Ibrahim et al., 2003; Parton et al., 2007). These neurons may modulate feedingand activity-related neural circuits by responding to slow metabolic cues in the hypothalamus.

Another key finding of this study is that acute activation of NTS POMC neurons leads to immediate suppression of food intake. Many neurons in the NTS of the medulla express POMC mRNA and are believed to synthesize POMC peptides (Bronstein et al., 1992). By delivering Cre-dependent AAV vectors, we found that POMC-Cre mice can be used to express the $\mathrm{CNO}$ receptor hM3Dq selectively in the putative POMC neurons in the NTS. Acute stimulation of NTS but not ARC POMC neurons was capable of suppressing feeding behavior, suggesting that the rapid inhibitory effect of melanocortins might be mediated by the neural circuits downstream of NTS POMC neurons (Fan et al., 1997). Electrical stimulation of vagal afferent fibers has been found to induce EPSCs directly in NTS POMC neurons (Appleyard et al., 2005). In addition, gastric distention and i.p. injection of the satiety signal cholecystokinin activates NTS neurons, a substantial number of which are believed to be POMC-ergic (Rinaman et al., 1998; Fan et al., 2004; Appleyard et al., 2005). Therefore, NTS POMC neurons may sense short-term satiety signals from visceral afferents to inhibit feeding behavior rapidly.

What might be the circuit mechanisms underlying the functional disparity between POMC neurons in the ARC and the NTS? The axonal terminals of ARC POMC neurons mainly terminate in the forebrain, including the paraventricular nucleus, dorsomedial hypothalamus, lateral hypothalamus, and central amygdala (Schwartz et al., 2000; Cone, 2005). These areas also receive strong input from ARC agouti-related protein neurons, which stimulate appetite and decrease metabolism powerfully (Aponte et al., 2011; Krashes et al., 2011). By interacting with agouti-related protein neurons, POMC neurons in the ARC may influence their downstream stations in the forebrain to adjust the set point of body weight and energy homeostasis. Conversely, NTS POMC neurons mainly project to the caudal medulla and spinal cord (Tsou et al., 1986; Palkovits et al., 1987; Zheng et al., 2005), where neural circuits may be more directly involved in executing satiety-trigged feeding suppression. In addition to distinct axonal projection targets, POMC neurons in the ARC and NTS differ in numbers. There are $\sim 3000$ POMC neurons in the ARC, whereas only $\sim 400$ POMC neurons are present in the NTS
(Hentges et al., 2004; Cone, 2005). Ablation of NTS POMC neurons lacks an obvious behavioral effect, possibly because of functional compensation by long-term activity of POMC neurons in the ARC and changes in other components of the feeding circuit (Pinto et al., 2004).

Our present results may also have clinical implications. Although loss-of-function mutations of the POMC genes are associated with early-onset obesity in humans (Krude et al., 1998), obesity can also be produced by mutations of melanocortin receptors or disorders that are indirectly related to the central melanocortin signaling (Farooqi et al., 2003). Nasal application of $\alpha$-MSH lacks consistent effects on treating human obesity (Hallschmid et al., 2004), raising questions about the validity of melanocortin-based therapeutics. Our present results show that chronic stimulation of POMC neurons can suppress daily food intake effectively and reduce body weight mildly. However, obesity can only be induced after $>80 \%$ of POMC neurons in the ARC are ablated, suggesting a large degree of redundancy in melanocortin signaling. Anti-obesity therapeutics based on melanocortins may require a personalized medical approach. Nasal application of $\alpha$-MSH may be rendered more effective by targeting obese persons with severe POMC deficiency.

\section{References}

Alexander GM, Rogan SC, Abbas AI, Armbruster BN, Pei Y, Allen JA, Nonneman RJ, Hartmann J, Moy SS, Nicolelis MA, McNamara JO, Roth BL (2009) Remote control of neuronal activity in transgenic mice expressing evolved G protein-coupled receptors. Neuron 63:27-39. CrossRef Medline

Aponte Y, Atasoy D, Sternson SM (2011) AGRP neurons are sufficient to orchestrate feeding behavior rapidly and without training. Nat Neurosci 14:351-355. CrossRef Medline

Appleyard SM, Bailey TW, Doyle MW, Jin YH, Smart JL, Low MJ, Andresen MC (2005) Proopiomelanocortin neurons in nucleus tractus solitarius are activated by visceral afferents: regulation by cholecystokinin and opioids. J Neurosci 25:3578-3585. CrossRef Medline

Armbruster BN, Li X, Pausch MH, Herlitze S, Roth BL (2007) Evolving the lock to fit the key to create a family of $\mathrm{G}$ protein-coupled receptors potently activated by an inert ligand. Proc Natl Acad Sci U S A 104:51635168. CrossRef Medline

Atasoy D, Aponte Y, Su HH, Sternson SM (2008) A FLEX switch targets Channelrhodopsin-2 to multiple cell types for imaging and long-range circuit mapping. J Neurosci 28:7025-7030. CrossRef Medline

Balthasar N, Coppari R, McMinn J, Liu SM, Lee CE, Tang V, Kenny CD, McGovern RA, Chua SC Jr, Elmquist JK, Lowell BB (2004) Leptin receptor signaling in POMC neurons is required for normal body weight homeostasis. Neuron 42:983-991. CrossRef Medline

Bjursell M, Gerdin AK, Lelliott CJ, Egecioglu E, Elmgren A, Törnell J, Oscarsson J, Bohlooly YM (2008) Acutely reduced locomotor activity is a major contributor to Western diet-induced obesity in mice. Am J Physiol Endocrinol Metab 294:E251-E260. CrossRef Medline

Bronstein DM, Schafer MK, Watson SJ, Akil H (1992) Evidence that betaendorphin is synthesized in cells in the nucleus tractus solitarius: detection of POMC mRNA. Brain Res 587:269-275. CrossRef Medline

Buch T, Heppner FL, Tertilt C, Heinen TJ, Kremer M, Wunderlich FT, Jung S, Waisman A (2005) A Cre-inducible diphtheria toxin receptor mediates cell lineage ablation after toxin administration. Nat Methods 2:419-426. CrossRef Medline

Challis BG, Coll AP, Yeo GS, Pinnock SB, Dickson SL, Thresher RR, Dixon J, Zahn D, Rochford JJ, White A, Oliver RL, Millington G, Aparicio SA, Colledge WH, Russ AP, Carlton MB, O’Rahilly S (2004) Mice lacking pro-opiomelanocortin are sensitive to high-fat feeding but respond normally to the acute anorectic effects of peptide-YY(3-36). Proc Natl Acad Sci U S A 101:4695-4700. CrossRef Medline

Coll AP, Farooqi IS, Challis BG, Yeo GS, O’Rahilly S (2004) Proopiomelanocortin and energy balance: insights from human and murine genetics. J Clin Endocrinol Metab 89:2557-2562. CrossRef Medline

Cone RD (2005) Anatomy and regulation of the central melanocortin system. Nat Neurosci 8:571-578. CrossRef Medline 
Cowley MA, Smart JL, Rubinstein M, Cerdán MG, Diano S, Horvath TL, Cone RD, Low MJ (2001) Leptin activates anorexigenic POMC neurons through a neural network in the arcuate nucleus. Nature 411:480-484. CrossRef Medline

Dong S, Rogan SC, Roth BL (2010) Directed molecular evolution of DREADDs: a generic approach to creating next-generation RASSLs. Nat Protoc 5:561-573. CrossRef Medline

Duan D, Yue Y, Engelhardt JF (2001) Expanding AAV packaging capacity with trans-splicing or overlapping vectors: a quantitative comparison. Mol Ther 4:383-391. CrossRef Medline

Fan W, Boston BA, Kesterson RA, Hruby VJ, Cone RD (1997) Role of melanocortinergic neurons in feeding and the agouti obesity syndrome. Nature 385:165-168. CrossRef Medline

Fan W, Ellacott KL, Halatchev IG, Takahashi K, Yu P, Cone RD (2004) Cholecystokinin-mediated suppression of feeding involves the brainstem melanocortin system. Nat Neurosci 7:335-336. CrossRef Medline

Farooqi IS, Keogh JM, Yeo GS, Lank EJ, Cheetham T, O’Rahilly S (2003) Clinical spectrum of obesity and mutations in the melanocortin 4 receptor gene. N Engl J Med 348:1085-1095. CrossRef Medline

Gong R, Ding C, Hu J, Lu Y, Liu F, Mann E, Xu F, Cohen MB, Luo M (2011) Role for the membrane receptor guanylyl cyclase-C in attention deficiency and hyperactive behavior. Science 333:1642-1646. CrossRef Medline

Gropp E, Shanabrough M, Borok E, Xu AW, Janoschek R, Buch T, Plum L, Balthasar N, Hampel B, Waisman A, Barsh GS, Horvath TL, Brüning JC (2005) Agouti-related peptide-expressing neurons are mandatory for feeding. Nat Neurosci 8:1289-1291. CrossRef Medline

Hallschmid M, Benedict C, Born J, Fehm HL, Kern W (2004) Manipulating central nervous mechanisms of food intake and body weight regulation by intranasal administration of neuropeptides in man. Physiol Behav 83:5564. CrossRef Medline

Hentges ST, Nishiyama M, Overstreet LS, Stenzel-Poore M, Williams JT, Low MJ (2004) GABA release from proopiomelanocortin neurons. J Neurosci 24:1578-1583. CrossRef Medline

Huo L, Grill HJ, Bjørbaek C (2006) Divergent regulation of proopiomelanocortin neurons by leptin in the nucleus of the solitary tract and in the arcuate hypothalamic nucleus. Diabetes 55:567-573. CrossRef Medline

Huo L, Gamber K, Greeley S, Silva J, Huntoon N, Leng XH, Bjørbaek C (2009) Leptin-dependent control of glucose balance and locomotor activity by POMC neurons. Cell Metab 9:537-547. CrossRef Medline

Ibrahim N, Bosch MA, Smart JL, Qiu J, Rubinstein M, Rønnekleiv OK, Low MJ, Kelly MJ (2003) Hypothalamic proopiomelanocortin neurons are glucose responsive and express K(ATP) channels. Endocrinology 144: 1331-1340. CrossRef Medline

Klockener T, Hess S, Belgardt BF, Paeger L, Verhagen LA, Husch A, Sohn JW, Hampel B, Dhillon H, Zigman JM, Lowell BB, Williams KW, Elmquist JK, Horvath TL, Kloppenburg P, Brüning JC (2011) High-fat feeding promotes obesity via insulin receptor/PI3K-dependent inhibition of SF-1 VMH neurons. Nat Neurosci 14:911-918. CrossRef Medline

Krashes MJ, Koda S, Ye C, Rogan SC, Adams AC, Cusher DS, Maratos-Flier E, Roth BL, Lowell BB (2011) Rapid, reversible activation of AgRP neurons drives feeding behavior in mice. J Clin Invest 121:1424-1428. CrossRef Medline

Krude H, Biebermann H, Luck W, Horn R, Brabant G, Grüters A (1998) Severe early-onset obesity, adrenal insufficiency and red hair pigmenta- tion caused by POMC mutations in humans. Nat Genet 19:155-157. CrossRef Medline

Luquet S, Perez FA, Hnasko TS, Palmiter RD (2005) NPY/AgRP neurons are essential for feeding in adult mice but can be ablated in neonates. Science 310:683-685. CrossRef Medline

McMinn JE, Wilkinson CW, Havel PJ, Woods SC, Schwartz MW (2000) Effect of intracerebroventricular alpha-MSH on food intake, adiposity, c-Fos induction, and neuropeptide expression. Am J Physiol Regul Integr Comp Physiol 279:R695-R703. Medline

Morton GJ, Cummings DE, Baskin DG, Barsh GS, Schwartz MW (2006) Central nervous system control of food intake and body weight. Nature 443:289-295. CrossRef Medline

Padilla SL, Carmody JS, Zeltser LM (2010) Pomc-expressing progenitors give rise to antagonistic neuronal populations in hypothalamic feeding circuits. Nat Med 16:403-405. CrossRef Medline

Padilla SL, Reef D, Zeltser LM (2012) Defining POMC neurons using transgenic reagents: impact of transient $\mathrm{POMC}$ expression in diverse immature neuronal populations. Endocrinology 153:1219-1231. CrossRef Medline

Palkovits M, Mezey E, Eskay RL (1987) Pro-opiomelanocortin-derived peptides (ACTH/beta-endorphin/alpha-MSH) in brainstem baroreceptor areas of the rat. Brain Res 436:323-338. CrossRef Medline

Parton LE, Ye CP, Coppari R, Enriori PJ, Choi B, Zhang CY, Xu C, Vianna CR, Balthasar N, Lee CE, Elmquist JK, Cowley MA, Lowell BB (2007) Glucose sensing by POMC neurons regulates glucose homeostasis and is impaired in obesity. Nature 449:228-232. CrossRef Medline

Pinto S, Roseberry AG, Liu H, Diano S, Shanabrough M, Cai X, Friedman JM, Horvath TL (2004) Rapid rewiring of arcuate nucleus feeding circuits by leptin. Science 304:110-115. CrossRef Medline

Ren J, Qin C, Hu F, Tan J, Qiu L, Zhao S, Feng G, Luo M (2011) Habenula "cholinergic" neurons co-release glutamate and acetylcholine and activate postsynaptic neurons via distinct transmission modes. Neuron 69: 445-452. CrossRef Medline

Rinaman L, Baker EA, Hoffman GE, Stricker EM, Verbalis JG (1998) Medullary c-Fos activation in rats after ingestion of a satiating meal. Am J Physiol 275:R262-R268. Medline

Schwartz MW, Woods SC, Porte D Jr, Seeley RJ, Baskin DG (2000) Central nervous system control of food intake. Nature 404:661-671. CrossRef Medline

Tsou K, Khachaturian H, Akil H, Watson SJ (1986) Immunocytochemical localization of pro-opiomelanocortin-derived peptides in the adult rat spinal cord. Brain Res 378:28-35. CrossRef Medline

Xu AW, Kaelin CB, Morton GJ, Ogimoto K, Stanhope K, Graham J, Baskin DG, Havel P, Schwartz MW, Barsh GS (2005) Effects of hypothalamic neurodegeneration on energy balance. PLoS Biol 3:e415. CrossRef Medline

Yaswen L, Diehl N, Brennan MB, Hochgeschwender U (1999) Obesity in the mouse model of pro-opiomelanocortin deficiency responds to peripheral melanocortin. Nat Med 5:1066-1070. CrossRef Medline

Zheng H, Patterson LM, Phifer CB, Berthoud HR (2005) Brain stem melanocortinergic modulation of meal size and identification of hypothalamic POMC projections. Am J Physiol Regul Integr Comp Physiol 289:R247-R258. CrossRef Medline

Zorrilla EP, Inoue K, Fekete EM, Tabarin A, Valdez GR, Koob GF (2005) Measuring meals: structure of prandial food and water intake of rats. Am J Physiol Regul Integr Comp Physiol 288:R1450-R1467. CrossRef Medline 